\title{
DISTRIBUTION OF BENTHIC MACROINVERTEBRATES \\ IN AN ARTIFICIALLY DESTRATIFIED \\ RESERVOIR
}

\author{
By \\ CARL JAMES FERRARIS, JR. \\ Bachelor of Science \\ Corne11 University \\ Ithaca, New York
}

1972

Submitted to the Faculty of the Graduate College of the Oklahoma State University in partial fulfillment of the requirements for the Degree of MASTER OF SCIENCE

May, 1976 
Thesis 1976 F368d
cop. 2 


\section{DISTRIBUTION OF BENTHIC MACROINVERTEBRATES}

IN AN ARTIFICIALLY DESTRATIFIED

RESERVOIR

Thesis Approved:

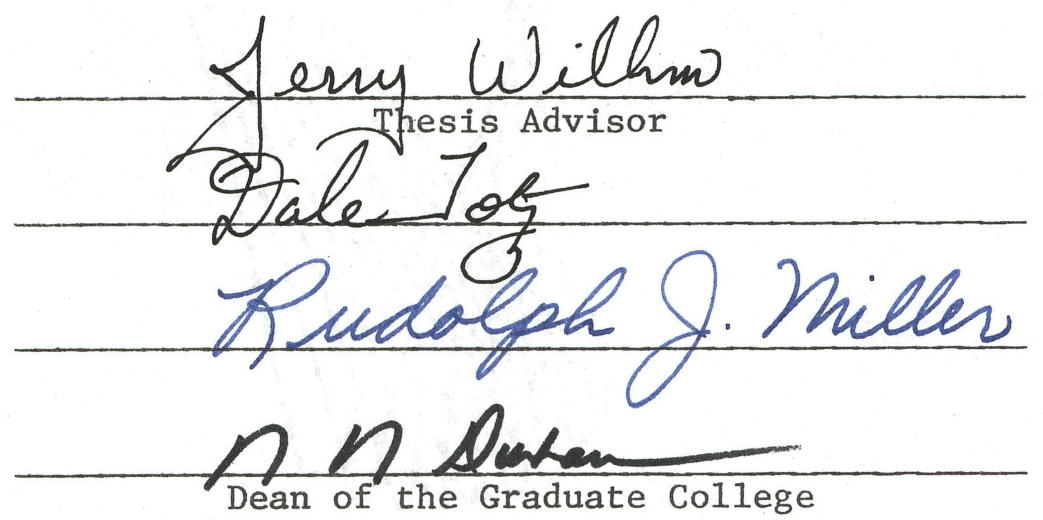

\section{3}




\section{ACKNOWLEDGMENTS}

Dr. Jerry Wilhm served as major advisor. Drs. Rudolph Miller and Dale Toetz served on the advisory committee and criticized the manuscript. Dr. Donald Holbert provided considerable assistance with the statistical analysis. The counsel of these men is appreciated. Assistance with the field collections and sorting of samples was provided by Alan Gaulke, Mike O'Hara, Jerry Wilhm, III, David Parrish, and John Parrish. Helen Murray typed the final copy of the thesis. Needed encouragement was provided at various times throughout my graduate program by John Heiser, Dr. and. Ms. Norman Durham, and my parents, Mr. and Ms. Carl Ferraris. My thanks goes to all these people. Special thanks is extended to Nancy McClintock, Mary Nagel, and Susan Durham who, by being themselves, helped make my stay in Oklahoma most enjoyable and profitable.

This study was part of a more extensive study of the effect of artificial destratification on the Ham's Lake ecosystem, and was supported, in part, by the Oklahoma Water Resources Research Institute and the Bureau of Reclamation. 


\section{TABLE OF CONTENTS}

$\begin{array}{lll}\text { Chapter } & \text { Page }\end{array}$

I. INTRODUCTION . . . . . . . . . . . . . . . . 1

II. STUDY AREA . . . . . . . . . . . . . . . . 4

III. MATERIALS AND METHODS . . . . . . . . . . . . 6

Preliminary Study . . . . . . . . . . . 6

Main Study .................. . . . 7

IV. RESULTS . . . . . . . . . . . . . . . . 10

Preliminary Study ............... . 10

Main Study . . . . . . . . . . . . . . 19

V. DISCUSSION . . . . . . . . . . . . . . 29

Benthic Macroinvertebrate Assemblage . . . . . 29

Depth Distribution of the Benthos . . . . . . . . 30

Effects of Physicochemical Conditions . . . . . 32

Effects of Artificial Destratification . . . . . . 33

VI. SUMMARY . . . . . . . . . . . . . . . . 36

LITERATURE CITED . . . . . . . . . . . . . . . . 38

APPENDIX ................................. 42 


\section{LIST OF TABLES}

Table

Page

1. Benthic macroinvertebrates collected in Ham's Lake from July, 1974 to July, 1975 . . . . . . . . . . . .

2. Number of species of benthic macroinvertebrates by station and depth during summer, 1974, in Ham's Lake .. . . . . . . . . . . . . . .

3. Density (individuals $/ \mathrm{m}^{2}$ ) of benthic macroinvertebrates by station and depth during summer, 1974, in Ham's Lake. . . . . . . . . . . . . . . .

4. Species diversity $(\bar{d})$ of populations of benthic macroinvertebrates by station and depth during summer, 1974, in Ham's Lake . . . . . . . . . . . .

5. Probability of interspecific encounter (PIE) of benthic macroinvertebrates by station and depth during summer, 1974, in Ham's Lake . . . . . . . . .

6. Physicochemical conditions of the bottom water ( $\mathrm{pH}$ is of the bottom sediments) over depth at Station 8 during 1975 in Ham's Lake . . . . . . . .

7. Numbers of species of benthic macroinvertebrates by depth at Station 8 during 1975 in Ham's Lake . . . .

8. Density (individuals $/ \mathrm{m}^{2}$ ) of benthic macroinvertebrates by depth at Station 8 during 1975 in Ham's Lake . . . . . . . . . . . . . . . .

9. Oven-dry weight $\left(\mathrm{g} / \mathrm{m}^{2}\right)$ of benthic macroinvertebrates by depth at Station 8 during 1975 in Ham's Lake . . . .

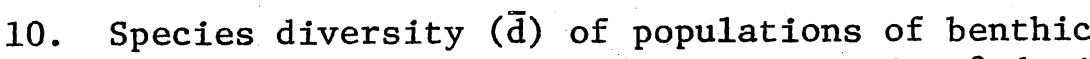
macroinvertebrates by depth at Station 8 during 1975 in Ham's Lake . . . . . . . . . . . . .

11. Probability of interspecific encounter (PIE) of benthic macroinvertebrates by depth at Station 8 during 1975 in Ham's Lake . . . . . . . . . . . .

12. Density (individuals $/ \mathrm{m}^{2}$ ) of benthic macroinvertebrates by station and depth in Ham's Lake on $13 \mathrm{July} 1974$. . . . . . . . . . . . . . . . . 
13. Density (individuals $/ \mathrm{m}^{2}$ ) of benthic macroinvertebrates by station and depth in Ham's Lake on on 30 July 1974 . . . . . . . . . . . . . .

14. Density (individuals $/ \mathrm{m}^{2}$ ) of benthic macroinvertebrates by station and depth in Ham's Lake on

22 August 1974

15. Density (individuals $/ \mathrm{m}^{2}$ ) of benthic macroinvertebrates by depth in Ham's Lake on 1 March 1975 . . . . .

16. Density (individuals $/ \mathrm{m}^{2}$ ) of benthic macroinvertebrates by depth in Ham's Lake on 21

May 1975 . . . . . . . . . . . . . .

17. Density (individuals $/ \mathrm{m}^{2}$ ) of benthic macroinvertebrates by depth in Ham's Lake on 14 June 1975 . . . .

18. Density (individuals $/ \mathrm{m}^{2}$ ) of benthic macroinvertebrates by depth in Ham's Lake on $10 \mathrm{July} 1975$. . . .

19. Density (individual $/ \mathrm{m}^{2}$ ) of benthic macroinvertebrates by depth in Ham's Lake on 31 July 1975 . . . . 


\section{LIST OF FIGURES}

\section{Figure}

Page

1. Ham's Lake showing sampling stations . . . . . . . . . 


\section{CHAPTER I}

\section{INTRODUCTION}

Benthic macroinvertebrates are not uniform1y distributed on the bottom of lakes and ponds. Variation with depth of species composition (Baker 1918, Saether 1970), density (Muttkowski 1918, Juday 1922, Inland Fisheries Branch 1970), species diversity (Ransom 1969), and biomass (McLachlan and McLachlan 1971, Fast 1971) has been reported. The presence of many organisms within a limited depth range has been referred to as a concentration zone (Eggleton 1931). Concentration zones, based both on density of individuals and biomass, varied with depth seasona1ly within lakes (Eggleton 1931, McLachlan and McLachlan 1971) and varied among nearby lakes sampled concomitantly (Eggleton 1935). Large concentrations of organisms, usually of only a few species, are often reported from deep profundal basins (Juday 1922). High diversity values have been reported from littoral collections (Ransom 1969). Collections made near the edge of exposed shorelines have yielded fewer species and individuals than in somewhat deeper water (Baker 1918, McLachlan and McLachlan 1971).

Seasonal changes in the depth distribution of benthic macroinvertebrates are often pronounced. The concentration zones may shift from near the shoreline in summer to the deep profundal during the winter (Eggleton 1931, McLachlan and McLachlan 1971). These shifts represent periodic migrations of some populations, changes in the 
relative abundances of taxa, and the colonization of the bottom by some species during part of the year (Eggleton 1931). Seasonal changes in the depth distribution of the benthos are most evident in the profundal zone. During periods of hypolimnion stagnation only a limited number of taxa inhabit the deep strata, while during turnover periods the composition of the profundal zone may be similar to the littoral zone (McLachlan and McLachlan 1971).

Eggleton (1931) separated the factors which influence the depth distribution of benthic macroinvertebrates into bottom characteristics, physiochemical factors, and biological factors. Bottom characteristics refer essentially to the nature and composition of materials which afford support, protection, and often a food source for the benthos. Distinct benthic assemblages have been associated with various bottom types (Baker 1918). Thermochemical stratification is the most important factor affecting the vertical distribution of the benthos (Eggleton 1931). Anoxic conditions of the profundal zone during periods of stratification are primarily responsible for the decrease in kinds and abundance of organisms (McLachlan and McLachlan 1971). In sha1lower areas of artifically constructed impoundments, reduced populations of benthic macroinvertebrates have been attributed to wave and current activities (Cowe1l and Hudson 1967) and high siltation rates (McLachlan and McLachlan 1971). Conductivity, $\mathrm{pH}$ of the water (Topping 1971), $\mathrm{pH}$ of the sediments, and Secchi disc visibility (Hilsenhoff and Narf 1968) have also been correlated with the presence or absence and abundance of populations of benthic macroinvertebrates.

Destratification and hypolimnion aeration may result in changes in the density and distribution of benthic macroinvertebrates (Toetz, 
Wilhm, and Summerfelt 1972). Destratification of a eutrophic lake enabled large numbers of chironomids and oligochaetes to reinvade the profundal zone (Inland Fisheries Branch 1970, Fast 1973). Hypolimnetic aeration of another eutrophic lake in which thermal stratification was maintained, extended the distribution of populations of benthic macroinvertebrates into deeper water (Fast 1971). Destratification of an oligotrophic lake (Fast 1971) and a montane mesotrophic lake (Lackey 1973) had little effect on the distribution of the benthos, although a decrease in the standing crops of chironomids was reported for both lakes.

Few principles exist for the depth distribution of benthic macroinvertebrates. In previous studies distribution was represented by only one or two parameters, usually number of species or density. The relationships among these variables has received little attention and, therefore, comparing results among studies is difficult. The factors regulating the distribution of the benthos are also 1ittle understood. The primary objectives of the present study were to (1) determine the variation with depth of density, number of species, biomass, and species diversity of the benthic macroinvertebrates in Ham's Lake; (2) determine the influence of dissolved oxygen, water temperature, conductivity, and $\mathrm{pH}$ of the sediments on the distribution of the benthic macroinvertebrate assemblage; and (3) determine the effect of destratification on the distribution of the benthos. 


\section{CHAPTER II}

\section{STUDY AREA}

Ham's Lake is located in Payne County, Oklahoma, about $8 \mathrm{~km}$ west of Stillwater (Figure 1). The lake was built in 1965 by the Soil Conservation Service as a flood detention reservoir. The surface area is 40 ha and the volume is 115 ha-m at principle spillway level (Steichen 1974). The deepest part of the lake is $9.5 \mathrm{~m}$ and the length of the central pool is about $1.3 \mathrm{~km}$. The drainage area is $1470 \mathrm{~km}^{2}$. During the summer, Ham's Lake stratifies thermally and chemically. The thermocline forms at $4 \mathrm{~m}$ and dissolved oxygen is depleted below that (Steichen 1974). In 1973, the lake was artifically destratified by pumping surface water to the bottom (Quintero and Garton 1973). Within 2 wk the lake was thermally destratified, but destratification of dissolved oxygen took longer. This same destratification technique was used in the present study.

Three stations were established for sampling benthic macroinvertebrates. Station 8 is a transect extending from the northwest part of the lake near the shore to the central pool, while Station 1 and 2 are transects in the southeast and southwest areas, respectively (Figure 1). The station numbers correspond to those used in concomitant studies in the lake. 

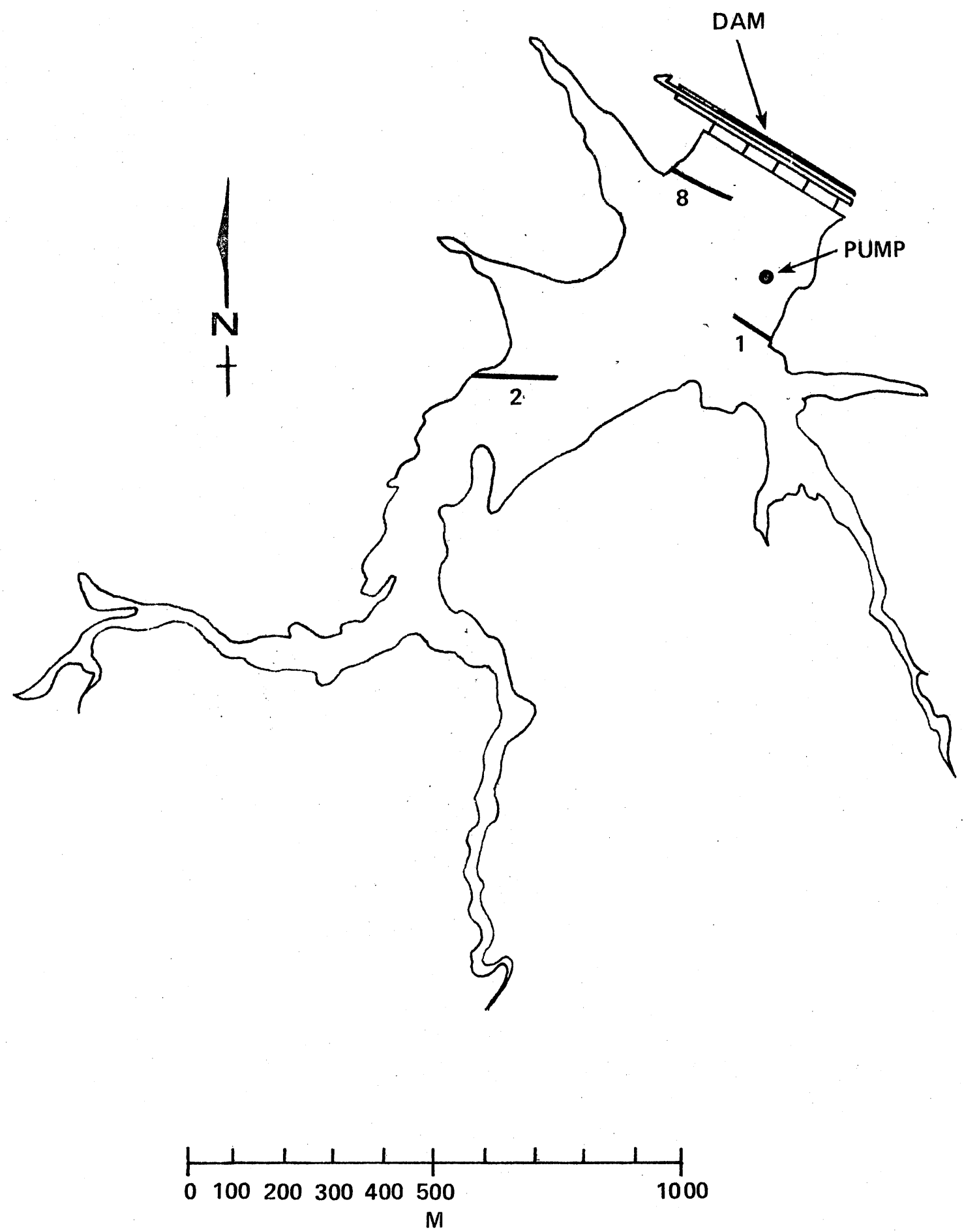

Figure 1。 Ham's Lake showing sampling stations 
CHAPTER III

MATERIALS AND METHODS

Preliminary Study

Depth distribution of benthic macroinvertebrates was studied at the three stations over three time periods in the summer, 1974. Samples were taken after pumping began on 13 May 1974. Three samples each were taken with an Ekman grab sampler at depths of 1,3, 5, and $8 \mathrm{~m}$ from each station on $13 \mathrm{Jui}$ 1974. Samples were washed in a U.S. standard 非30 soil sieve and preserved in $8 \%$ formalin. The time required to sort and identify organisms necessitated reducing the number of samples during the subsequent sampling periods. Since considerable variation existed among replicate samples, replication was not decreased. The number of stations sampled was not reduced since this was a preliminary study of the lake. Thus, during the collections of $30 \mathrm{Jul}$ and 22 Aug 1974, the 3 and $5 \mathrm{~m}$ depths were combined into a single collecting depth of $4.5 \mathrm{~m}$. Identification was to species when possible; otherwise, identification was to the lowest practical taxon. Nomenclature followed Pennak (1953), Brinkhurst and Jamison (1973), and Mason (1973). Identification was aided by keys and descriptions in Usinger (1971), Beck (1968), Beck and Beck (1966), Brinkhurst $(1964,1965)$, and Brinkhurst and Cook (1966). Species diversity was determined by the formula (Shannon and Weaver 1963): 


$$
\overline{\mathrm{d}}=-\sum_{i=1}^{s}\left(n_{i} / \mathrm{n}\right) \log _{2}\left(\mathrm{n}_{i} / \mathrm{n}\right)
$$

and by Hurlbert's (1971) formula for the probability of interspecific encounter (PIE):

$$
\operatorname{PIE}=n /(n-1) \sum_{i=1}^{s}\left(n_{i} / n\right) \cdot\left(\left[n-n_{i}\right] /[n-1]\right)
$$

where: $n_{i}=$ number of individuals of the taxon

$$
\begin{aligned}
& \mathrm{n}=\text { total number of individuals, and } \\
& \mathrm{s}=\text { total number of species. }
\end{aligned}
$$

Shannon's formula was first adopted as a measure of community diversity by Patten (1962). The PIE formula was modified from Simpson's (1949) formula for the measure of concentration. Both measures are unbiased estimators which level off as sample size increases (Wilhm and Dorris 1968, Hurlbert 1971). Wilhm found that multiple Ekman grab samples were almost always required to reach an asymptotic level of $\bar{d}$. Thus, a single diversity estimate was made from pooled replicate samples.

\section{Main Study}

The data collected in summer, 1974, revealed that variation among depths was considerably greater than variation among stations and that considerable variation existed among replicate samples. In 1975, four samples were taken from each of eight depths at Station 8. The depths were at $1 \mathrm{~m}$ intervals from 1 to $8 \mathrm{~m}$ and the samples were taken on 1 Mar, 21 May, $14 \mathrm{Jun}, 10 \mathrm{Ju} 1$, and $31 \mathrm{Ju} 1$. The latter two samples were taken after pumping operations began on 19 Jun. Samples were sorted and identified as described for the preliminary study. Three addi- 
tional samples were taken from each of the eight depths every sampling period. Oven-dry weight of the organisms from these samples was determined by gravimetric analysis (Weber 1973).

Three measurements each of temperature, dissolved oxygen, and conductivity were made of the water just above the mud-water interface at each depth. The bottom sediments at each depth were analyzed for $\mathrm{pH}$. Temperature and dissolved oxygen were measured with an air calibrated Yellow Springs Instrument (YSI) model 54 oxygen meter. Specific conductance and $\mathrm{pH}$ were measured with a YSI mode1 33 salinityconductivity-temperature meter and an Orion mode1 407 specific ion meter, respective1y.

This study was designed to be analyzed as a factorial arrangement of treatments; the treatments being depths, sampling periods, and during the preliminary study, stations. Treatments were judged to be significantly different when the $0 S L \leq 0.01$. Correlations among physicochemical parameters and characteristics of the benthic assemblage were observed with the aid of product-moment correlation coefficients and canonical correlation analysis. Data from the main study were tested against the following models:

$$
\begin{aligned}
\text { Index } & =B_{0}+B_{1} D+B_{2} D^{2}+B_{3} D^{3} \\
\text { Log Index } & =B_{0}+B_{1} D+B_{2} D^{2}+B_{3} D^{3} \\
\text { Index } & =B_{0}+B_{1} \text { Disso }{ }_{2}+B_{2} \text { Temp }+B_{3} \text { Cond }+B_{4} p H+B_{5} D
\end{aligned}
$$

where: $B_{i}$ 's were least square fit coefficients $\mathrm{D}=$ depth DissO $_{2}$, Temp, Cond, and $\mathrm{pH}$ were physicochemical data and, Index = Biomass, Number of species, or density. 
Models (1) and (2) test whether knowledge of depth, as simple linear, quadratic, or cubic functions, were valuable as predictors of the density, biomass, or number of species of the benthic assemblage. Model (3) was used to determine whether knowledge of the physicochemical conditions of the water and substrate could be used to predict the density, biomass, or number of species of the benthos. 
CHAPTER IV

RESULTS

Preliminary Study

of the 67 species of benthic macroinvertebrates collected in Ham's Lake during the study (Table 1), 45 were taken during 1974. During summer, 1974, only four taxa, Chaoborus punctipennis, Chironomus sp., and Tanypus sp., were found at all depths on all three sampling dates. Ten species were found only at $1 \mathrm{~m}$, the only three odonates taken during 1974, Macromia sp., Epicordulia sp., and Somatochlora sp., and seven chironomids of the tribe Chironomini. Six additional taxa were found only at the shallow and middle depths including all of the mayfly nymphs, chironomids of the tribe Pentaneurini, and Harnischia sp.

The number of species collected in 1974 by station and depth varied from 2 to 17 (Table 2). One meter samples generally contained more species $(\bar{x}=8.9)$ than the middle or deep water stations $(\bar{x}=5.2$ and 3.5, respectively). A tendency existed for the number of species collected to increase slightly during the summer. Variation among stations existed, but was considerably less than variation among depths.

The density of the benthic macroinvertebrate assemblage ranged from 114 to 4686 organisms $/ \mathrm{m}^{2}$ (Table 3). A consistant variation in density among stations was not observed. Density increased signifi- 
Table 1. Benthic macroinvertebrates collected in Ham's Lake from July, 1974 to July, 1975.

Coelenterata

Hydrozoa

Hydra sp.

Platyhelminthes

Turbellaria

Dugesia sp.

Nematoda

Undidentifiable species

Annelida

01igochaeta

Chaetogaster sp.

Dero digitata (Mü1ler)

Nais sp.

Stylaria lacustris (Linn.)

Aulodrilus pigueti Kowalewski

Ilyodrilus sp.

Limnodrilus hoffmeisteri Clap.

L. cervix Brinkhurst

L. claparedianus Ratzel

$\overline{\mathrm{L}}$. undekemianus $\mathrm{Clap}$.

Tubifex tubifex (Müller)

Unidentifiable tubificid w/capilliform chaetae

Unidentifiable tubificid w/out capilliform chaetae

Arthropoda

Arachnida

Hydracarina spp.

Crustacea

Unidentifiable Astacidae

Hyalella azteca (Saussure)

Insecta

Ephemeroptera

Hexagenia limbata (Serville)

Caenis sp.

Cloeon sp.

Centroptitum sp.

Unidentifiable Baetidae

Odonata

Gomphus sp.

Epicordulia sp.

Macromia sp.

Plathemis sp.

Somatochlora sp.

Sympetrum sp.

Ischnura sp. 
Table 1. (Continued)

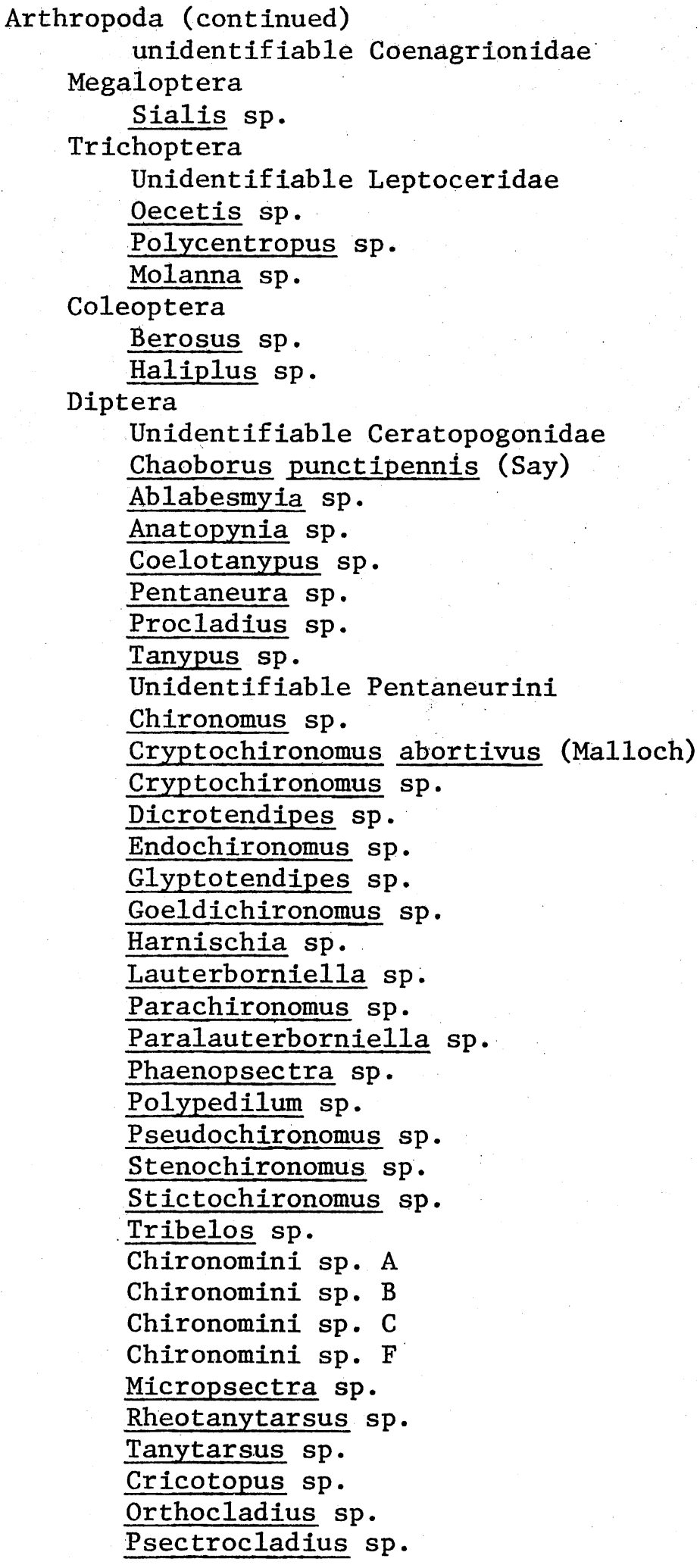


Table 1. (Continued)

Arthropoda (continued)

Chironomid pupae

Mollusca

Pelecypoda

Pisidium sp.

Gastropoda

Gyralus sp.

Physa sp. 
Table 2. Number of species* of benthic macroinvertebrates by station and depth during summer, 1974, in Ham's Lake.

\begin{tabular}{ccrrr}
\hline Station & $\begin{array}{c}\text { Depth } \\
(\mathrm{m})\end{array}$ & $\begin{array}{r}13 \\
\text { JuI }\end{array}$ & $\begin{array}{r}30 \\
\text { Jul }\end{array}$ & $\begin{array}{r}22 \\
\text { Aug }\end{array}$ \\
\hline \multirow{2}{*}{8} & 1 & 13 & 17 & 16 \\
& 3 & 9 & - & - \\
& $5 * *$ & 7 & 3 & 10 \\
& 8 & 4 & 3 & 4 \\
1 & 1 & 12 & 12 & 16 \\
& 3 & 8 & - & - \\
& $5 * *$ & 10 & 6 & 9 \\
& 8 & 8 & 6 & 7 \\
2 & 1 & 9 & 15 & 17 \\
& 3 & 9 & - & - \\
& $5 * *$ & 9 & 7 & 10 \\
& 8 & 8 & 2 & 5 \\
\hline
\end{tabular}

*Values are number of species in three Ekman grab samples.

$* *$ Depth $=4.5 \mathrm{~m}$ on $30 \mathrm{Ju} 1$ and 22 Aug.

- = Sample not taken. 
Table 3. Density (individuals $/ \mathrm{m}^{2}$ )* of benthic macroinvertebrates by station and depth during summer, 1974, in Ham's Lake.

\begin{tabular}{ccrrr}
\hline Station & $\begin{array}{c}\text { Depth } \\
(\mathrm{m})\end{array}$ & $\begin{array}{r}13 \\
\mathrm{Ju1}\end{array}$ & $\begin{array}{r}30 \\
\mathrm{Ju1}\end{array}$ & $\begin{array}{r}22 \\
\text { Aug }\end{array}$ \\
\hline \multirow{2}{*}{8} & 1 & 1032 & 3341 & 1792 \\
& 3 & 659 & - & - \\
& $5 * *$ & 315 & 114 & 543 \\
& 8 & 114 & 773 & 961 \\
1 & 1 & 931 & 832 & 2810 \\
& 3 & 931 & - & - \\
& $5 * *$ & 501 & 644 & 903 \\
& 8 & 1348 & 1677 & 4648 \\
2 & & & & \\
& 1 & 614 & 1532 & 716 \\
& 3 & 615 & - & - \\
& $5 * *$ & 759 & 816 & 773 \\
& 8 & 445 & 129 & 1047 \\
\hline
\end{tabular}

*Values are mean densities of three Ekman grab samples.

**Depth $=4.5 \mathrm{~m}$ on $30 \mathrm{Ju} 1$ and $22 \mathrm{Aug}$.

- = Samples not taken. 
cantly (OSL <.001) with time, primarily due to a large increase in the Chaoborus population. The fauna of the shallow depths was dominated by the chironomids Tanytarsus sp. and Procladius sp. (Tables 1214). In August, Tanypus sp. and Chironomus sp. were also found in considerable numbers at $1 \mathrm{~m}$. The middle depths were again dominated by Procladius, Chironomus, and Tanypus, but all three were less abundant than in the shallow water. No one taxon was consistantly found in large numbers at $8 \mathrm{~m}$. Chironomus and Tanypus were abundant in midJuly, especially at Station 1. During the latter two sampling periods, these two decreased in abundance in deep water and large numbers of Chaoborus were collected.

Species diversity $(\bar{d})$ of benthic macroinvertebrates ranged from 0.3 to 3.6 (Table 4). Probability of interspecific encounter (PIE) ranged from .07 to .89 (Table 5) and was highly correlated with the $\overline{\mathrm{d}}$ values. Diversity varied little among stations and was nearly uniform at all depths on $13 \mathrm{Jul}$. On $30 \mathrm{JuI}$ and 22 Aug, $\overline{\mathrm{d}}$ and PIE decreased consistantly with depth at all stations. The low values at 4.5 and $8 \mathrm{~m}$ were primarily the result of a decrease in the number of species and an increase in the Chaoborus population.

Data from the preliminary study indicated that variation among depths and over time of the species composition and diversity of the benthic macroinvertebrate assemblage was greater than variation among stations. Thus, in the more intensive sampling program conducted in 1975, physicochemical measurements and invertebrate samples were collected from $1 \mathrm{~m}$ intervals along the transect at Station 8. Sampling was conducted during periods of natural destratification (spring), stratification (early summer), and artificial destratification (1ate 
Table 4. Species diversity $(\bar{d}) *$ of populations of benthic macroinvertebrates by station and depth during summer, 1974, in Ham's Lake.

\begin{tabular}{|c|c|c|c|c|}
\hline Station & $\begin{array}{l}\text { Depth } \\
\text { (m) }\end{array}$ & $\begin{array}{r}13 \\
\mathrm{Ju} 1\end{array}$ & $\begin{array}{r}30 \\
\mathrm{Ju} 1\end{array}$ & $\begin{array}{r}22 \\
\text { Aug }\end{array}$ \\
\hline 8 & $\begin{array}{l}1 \\
3 \\
5 * * \\
8\end{array}$ & $\begin{array}{l}3.2 \\
1.8 \\
2.6 \\
1.7\end{array}$ & $\begin{array}{c}2.3 \\
- \\
1.0 \\
0.3\end{array}$ & $\begin{array}{c}3.1 \\
- \\
2.5 \\
0.8\end{array}$ \\
\hline 1 & $\begin{array}{l}1 \\
3 \\
5 * * \\
8\end{array}$ & $\begin{array}{l}2.2 \\
1.8 \\
2.7 \\
2.3\end{array}$ & $\begin{array}{c}2.8 \\
- \\
1.9 \\
0.8\end{array}$ & $\begin{array}{c}2.9 \\
- \\
2.5 \\
0.5\end{array}$ \\
\hline 2 & $\begin{array}{l}1 \\
3 \\
5 * * \\
8\end{array}$ & $\begin{array}{l}2.2 \\
2.8 \\
2.7 \\
2.6\end{array}$ & $\begin{array}{c}2.8 \\
- \\
2.0 \\
1.0\end{array}$ & $\begin{array}{c}3.6 \\
- \\
2.6 \\
1.6\end{array}$ \\
\hline
\end{tabular}

*Values are total diversity of three pooled samples.

**Depth $=4.5 \mathrm{~m}$ on $30 \mathrm{Jul}$ and $22 \mathrm{Aug}$.

- = Samples not taken. 
Table 5. Probability of interspecific encounter (PIE)* of benthic macroinvertebrates by station and depth during summer, 1974, in Ham's Lake.

\begin{tabular}{|c|c|c|c|c|}
\hline Station & $\begin{array}{l}\text { Depth } \\
\text { (m) }\end{array}$ & $\begin{array}{r}13 \\
\mathrm{Ju} 1\end{array}$ & $\begin{array}{r}30 \\
\mathrm{Ju} 1\end{array}$ & $\begin{array}{r}22 \\
\text { Aug }\end{array}$ \\
\hline 8 & $\begin{array}{l}1 \\
3 \\
5 * * \\
8\end{array}$ & $\begin{array}{r}.79 \\
.52 \\
.83 \\
.73\end{array}$ & $\begin{array}{c}.70 \\
- \\
.07 \\
.07\end{array}$ & $\begin{array}{c}.83 \\
- \\
.77 \\
.27\end{array}$ \\
\hline 1 & $\begin{array}{l}1 \\
3 \\
5 * * \\
8\end{array}$ & $\begin{array}{l}.62 \\
.56 \\
.80 \\
.75\end{array}$ & $\begin{array}{c}.80 \\
- \\
.69 \\
.28\end{array}$ & $\begin{array}{c}.82 \\
- \\
.78 \\
.11\end{array}$ \\
\hline 2 & $\begin{array}{l}1 \\
3 \\
5 * * \\
8\end{array}$ & $\begin{array}{l}.76 \\
.83 \\
.81 \\
.81\end{array}$ & $\begin{array}{c}.80 \\
- \\
.64 \\
.50\end{array}$ & $\begin{array}{c}.89 \\
- \\
.77 \\
.55\end{array}$ \\
\hline
\end{tabular}

*Values are total probability based on three pooled samples.

$* *$ Depth $=4.5 \mathrm{~m}$ on $30 \mathrm{Jul}$ and $22 \mathrm{Aug}$.

- = Sample not taken. 
summer) to determine the immediate influence of artificial destratification on the depth distribution of the benthos.

\section{Main Study}

Temperature, dissolved oxygen, and conductivity of the bottom water and $\mathrm{pH}$ of the sediments in Ham's Lake were relatively uniform over depth at Station 8 on 1 Mar 1975 (Table 6). The level of dissolved oxygen decreased considerably at all depths between 1 Mar and 21 May. On 21 May an abrupt decrease in dissolved oxygen occurred between 3 and $4 \mathrm{~m}$, while conductivity decreased abruptly between 4 and $5 \mathrm{~m}$. No consistent pattern was observed for $\mathrm{pH}$ of the sediments. On 14 Jun, just prior to the beginning of pumping operations, the deep water was almost devoid of oxygen and a considerable decrease in oxygen and temperature occurred between 5 and $6 \mathrm{~m}$. Conductivity decreased slightly with depth. On $10 \mathrm{Jul}$, about 3 weeks after pumping began, the water temperature was relatively uniform at all depths. The sharpest decrease in dissolved oxygen on this date occurred between 1 and $2 \mathrm{~m}$. Between 14 Jun and $10 \mathrm{Ju}$, oxygen decreased in the shallow waters and increased in the bottom waters possibly as a result of pumping. The decrease in conductivity with depth that was observed on 21 May and 14 Jun was not apparent on $10 \mathrm{Jul}$. Because of a malfunction in the meter $\mathrm{pH}$ was not measured on this date. On $31 \mathrm{Jul}$ dissolved oxygen as well as temperature was relatively uniform at all depths and values were similar to those measured on $10 \mathrm{Jul}$. A dense growth of macrophytes at 1 and $2 \mathrm{~m}$ on $31 \mathrm{Ju} 1$ prevented collecting of benthic macroinvertebrates and thus measurements of temperature and oxygen were not taken on this date. Malfunction of the conductivity meter prevented measurements of 
Table 6。 Physicochemical conditions* of the bottom water $(\mathrm{pH}$ is of the bottom sediments) over depth at Station 8 during 1975 in Ham's Lake。

\begin{tabular}{|c|c|c|c|c|c|}
\hline Date & $\begin{array}{l}\text { Water } \\
\text { Depth } \\
\text { (m) }\end{array}$ & $\begin{array}{c}\text { Temperature } \\
(\mathrm{C})\end{array}$ & $\begin{array}{c}\text { Oxygen } \\
(\mathrm{mg} / 1)\end{array}$ & $\begin{array}{c}\text { Conducti'vity } \\
\text { (umhos) }\end{array}$ & $\mathrm{pH}$ \\
\hline 1 Mar & $\begin{array}{l}1 \\
2 \\
3 \\
4 \\
5 \\
6 \\
7 \\
8\end{array}$ & $\begin{array}{l}5.7 \\
5.5 \\
5.0 \\
5.4 \\
5.0 \\
5.0 \\
5.1 \\
5.2\end{array}$ & $\begin{array}{r}12.3 \\
11.8 \\
11.7 \\
11.3 \\
13.1 \\
9.5 \\
11.9 \\
12.5\end{array}$ & $\begin{array}{l}203 \\
205 \\
203 \\
201 \\
205 \\
202 \\
208 \\
209\end{array}$ & $\begin{array}{l}7.8 \\
7.5 \\
7.9 \\
7.3 \\
7.4 \\
7.3 \\
7.2 \\
8.0\end{array}$ \\
\hline 21 May & $\begin{array}{l}1 \\
2 \\
3 \\
4 \\
5 \\
6 \\
7 \\
8\end{array}$ & $\begin{array}{l}17.8 \\
17.5 \\
17.5 \\
17.8 \\
20.4 \\
20.4 \\
20.7 \\
16.2\end{array}$ & $\begin{array}{l}7.8 \\
7.3 \\
8.0 \\
3.7 \\
3.1 \\
3.3 \\
3.2 \\
2.5\end{array}$ & $\begin{array}{l}322 \\
318 \\
320 \\
303 \\
215 \\
207 \\
188 \\
216\end{array}$ & $\begin{array}{l}6.8 \\
7.3 \\
7.3 \\
7.8 \\
7.7 \\
8.0 \\
7.1 \\
5.9\end{array}$ \\
\hline 14. Jun & $\begin{array}{l}1 \\
2 \\
3 \\
4 \\
5 \\
6 \\
7 \\
8\end{array}$ & $\begin{array}{l}23.0 \\
22.5 \\
22.5 \\
22.5 \\
22.5 \\
19.0 \\
18.0 \\
18.0\end{array}$ & $\begin{array}{l}7.7 \\
7.3 \\
7.0 \\
6.1 \\
6.2 \\
0.2 \\
0.1 \\
0.1\end{array}$ & $\begin{array}{l}335 \\
330 \\
330 \\
345 \\
340 \\
337 \\
303 \\
305\end{array}$ & $\begin{array}{l}6.9 \\
7.4 \\
7.6 \\
7.8 \\
7.1 \\
6.8 \\
7.1 \\
6.9\end{array}$ \\
\hline $10 \mathrm{Ju} 1$ & $\begin{array}{l}1 \\
2 \\
3 \\
4 \\
5 \\
6 \\
7 \\
8\end{array}$ & $\begin{array}{l}30.0 \\
29.0 \\
29.0 \\
28.5 \\
28.5 \\
28.5 \\
28.5 \\
28.0\end{array}$ & $\begin{array}{l}6.4 \\
3.9 \\
3.4 \\
2.6 \\
2.6 \\
2.8 \\
2.5 \\
1.7\end{array}$ & $\begin{array}{l}396 \\
410 \\
432 \\
419 \\
419 \\
420 \\
420 \\
447\end{array}$ & $\begin{array}{l}6.9 \\
* * \\
* * \\
* * \\
* * \\
* * \\
* * \\
* *\end{array}$ \\
\hline $31 \mathrm{JuI}$ & $\begin{array}{l}1 \\
2 \\
3 \\
4 \\
5 \\
6 \\
7 \\
*\end{array}$ & $\begin{array}{r}* * \\
* * \\
28.2 \\
28.0 \\
28.0 \\
28.0 \\
28.0 \\
28.0\end{array}$ & $\begin{array}{l}* * \\
* * \\
2.4 \\
2.5 \\
2.9 \\
2.6 \\
1.3 \\
2.3\end{array}$ & $\begin{array}{l}* * \\
* * \\
* * \\
* * \\
* * \\
* * \\
* * \\
* *\end{array}$ & $\begin{array}{r}* * \\
* * \\
6.3 \\
7.5 \\
7.0 \\
6.9 \\
6.5 \\
7.5\end{array}$ \\
\hline
\end{tabular}

*Values are means of three measurements

**Values not measured 
this parameter on $31 \mathrm{Jul}$.

Fifty-seven taxa of benthic macroinvertebrates were collected from Ham's Lake in 1975. The species collected differed only slightly from those collected in 1974. A few additional species were found because of the increased sampling effort. Chironomus sp. and Tanypus sp., which were found infrequently in 1975, were abundant in Ham's Lake the previous year. The reverse trend was observed for Dero digitata. One specimen was found in the 1974 samples while Dero was the most abundant organism in 1975.

Chaoborus punctipennis, Coelotanypus sp., and Dero digitata were collected during each sampling period (Tables 15-19). Eighteen taxa were taken only from the 1 and $2 \mathrm{~m}$ samples, all but Gyralus sp. and Hyale1la azteca were rare. Most species of benthic organisms found below $2 \mathrm{~m}$ were also taken from the shallow water. The exceptions to this were Pisidium sp., Lauterborniella sp. and an unidentified chironomid, Chironomini F. Pisidium was found from 3 to $6 \mathrm{~m}$ and the two chironomids were found at 6 and $8 \mathrm{~m}$, respectively.

Numbers of species tended to decrease with depth as in 1974 (Table 7). A marked decrease occurred between 1 and $2 \mathrm{~m}$. Significant changes generally were not observed between the 2 to $8 \mathrm{~m}$ depths in the March and the May samples. However, a pronounced decrease in number of species occurred between 4 and $5 \mathrm{~m}$ on $14 \mathrm{Jun}$ and $10 \mathrm{Jul}$. Samples from 5 to $8 \mathrm{~m}$ on both of these dates had considerably fewer species than existed in the profundal zone in March and May. By $31 \mathrm{Ju} 1$, the total number of species found in the profundal zone increased from the previous sample.

Mean benthic macroinvertebrate density ranged from 75 to 16,639 
Table 7. Numbers of species* of benthic macroinvertebrates by depth at Station 8 during 1975 in Ham's Lake.

\begin{tabular}{cccccc}
\hline $\begin{array}{c}\text { Depth } \\
(\mathrm{m})\end{array}$ & $\begin{array}{c}1 \\
\text { Mar }\end{array}$ & $\begin{array}{r}21 \\
\text { May }\end{array}$ & $\begin{array}{c}14 \\
\text { Jun }\end{array}$ & $\begin{array}{r}10 \\
\mathrm{JuI}\end{array}$ & $\begin{array}{r}31 \\
\mathrm{Ju} 1\end{array}$ \\
\hline 1 & 29 & 30 & 25 & 20 & - \\
2 & 20 & 7 & 13 & 13 & 14 \\
3 & 11 & 11 & 11 & 15 & 17 \\
4 & 5 & 10 & 11 & 11 & 10 \\
5 & 9 & 9 & 5 & 4 & 3 \\
6 & 12 & 8 & 4 & 5 & 10 \\
7 & 7 & 9 & 4 & 6 & 5 \\
8 & 9 & 7 & 5 & 4 & 8 \\
\hline
\end{tabular}

*Values are numbers of species in four Ekman grab samples.

- = Samples not taken.

Vertical line designates beginning of pumping (i.e., 19 Jun 1975). 
organisms $/ \mathrm{m}^{2}$ (Table 8). Density decreased significantly (OSL $\left.<0.001\right)$ with time. On 1 Mar, the shallow water samples were dominated by Dero digitata, Aulodrilus pigueti, ceratopogonids, and Ilyodrilus sp. Large numbers of Dicrotendipes sp., Procladius sp., Tanytarsus sp., Hyalella azteca, and Hexagenia limbata were also found. Most of these taxa were found in reduced numbers in the mid-depths and only three were found at $8 \mathrm{~m}$. The large density at the 5 to $8 \mathrm{~m}$ depths was primarily due to the presence of one species, Chaoborus punctipennis. On 21 May, the benthic assemblage was essentially the same in composition and distribution as on 1 Mar, but in reduced numbers. A $98 \%$ reduction occurred in the density of Chaoborus in the profundal zone. Aulodrilus pigueti and Dictotendipes were also found in greatly reduced numbers. Density was even smaller on 14 Jun. Most populations continued to decline in abundance, only Chaoborus and Hyalella increased substantially. Chaoborus, although considerably reduced from March levels, accounted for over $90 \%$ of the benthic invertebrates below $4 \mathrm{~m}$. On $10 \mathrm{Jul}$, the average density of Hyalella and Chaoborus was reduced to $25 \%$ of its spring level of 400 organisms $/ \mathrm{m}^{2}$. Stylaria lacustris, which had been found in excess of 1000 organisms $/ \mathrm{m}^{2}$ at the $1 \mathrm{~m}$ depths in the spring and early summer, was not taken in Jul. On $31 \mathrm{Jul}$, the profundal zone supported a larger density, while shallower water populations continued to decrease.

The oven-dry weight of benthic macroinvertebrates ranged from 0.01 to $5.83 \mathrm{~g} / \mathrm{m}^{2}$ (Table 9). The greatest values were generally found at 1 and $2 \mathrm{~m}$ and except for the Mar sample, biomass generally decreased with depth. The decrease was pronounced from 1 to $3 \mathrm{~m}$ and slight below that. Variation of biomass over time was not significant. 
Table 8. Density (individuals $/ \mathrm{m}^{2}$ )* of benthic macroinvertebrates by depth at Station 8 during 1975 in Ham's Lake.

\begin{tabular}{lrrrrr}
\hline $\begin{array}{c}\text { Depth } \\
(\mathrm{m})\end{array}$ & $\begin{array}{c}1 \\
\text { Mar }\end{array}$ & $\begin{array}{r}21 \\
\text { May }\end{array}$ & $\begin{array}{r}14 \\
\text { Jun }\end{array}$ & $\begin{array}{r}10 \\
\text { Ju1 }\end{array}$ & $\begin{array}{r}31 \\
\text { Ju1 }\end{array}$ \\
\hline 1 & 16639 & 9240 & 6038 & 1079 & - \\
2 & 3058 & 1259 & 605 & 2465 & 959 \\
3 & 1357 & 2229 & 1141 & 1901 & 2382 \\
4 & 144 & 814 & 453 & 506 & 400 \\
5 & 1013 & 647 & 119 & 194 & 75 \\
6 & 2908 & 496 & 635 & 205 & 593 \\
7 & 3197 & 444 & 851 & 335 & 495 \\
8 & 5878 & 529 & 711 & 506 & 603 \\
\hline
\end{tabular}

*Values are mean densities of four Ekman grab samples.

- = Samples not taken.

Vertical line designates beginning of pumping (i.e., 19 Jun 1975). 
Table 9. Oven-dry weight $\left(\mathrm{g} / \mathrm{m}^{2}\right) *$ of benthic macroinvertebrates by depth at Station 8 during 1975 in Ham's Lake.

\begin{tabular}{cccccr}
\hline $\begin{array}{c}\text { Depth } \\
(\mathrm{m})\end{array}$ & $\begin{array}{c}1 \\
\text { Mar }\end{array}$ & $\begin{array}{r}21 \\
\text { May }\end{array}$ & $\begin{array}{r}14 \\
\text { Jun }\end{array}$ & $\begin{array}{r}10 \\
\mathrm{Ju} 1\end{array}$ & $\begin{array}{r}31 \\
\mathrm{Ju} 1\end{array}$ \\
\hline 1 & 2.23 & 1.14 & 1.69 & 5.83 & - \\
2 & 0.78 & 1.21 & 0.41 & 0.93 & 0.20 \\
3 & 0.73 & 0.67 & 0.67 & 0.82 & 0.35 \\
4 & 0.09 & 0.27 & 0.06 & 0.30 & 0.24 \\
5 & 0.09 & 0.21 & 0.02 & 0.11 & 0.01 \\
6 & 0.37 & 0.06 & 0.08 & 0.27 & 0.40 \\
7 & 1.22 & 0.11 & 0.18 & 0.09 & 0.19 \\
8 & 0.59 & 0.27 & 0.16 & 0.12 & 0.10 \\
\hline
\end{tabular}

*Values are mean estimates based on three Ekman grab samples.

- = Sample not taken.

Vertical line designates beginning of pumping (i.e., 19 Jun 1975). 
Species diversity $(\bar{d})$ ranged from 0.5 to 3.3 (Table 10). Diversity decreased significantly with depth on $1 \mathrm{Mar}, 14 \mathrm{Jun}$, and $10 \mathrm{Ju} 1$ (OSL $<.001, .005, .002$, respectively), but was not significantly correlated with depth on 21 May and 31 Jul. On 1 Mar, $\bar{d}$ decreased uniformly with depth, while values decreased abruptly between 5 and $6 \mathrm{~m}$ on $14 \mathrm{Jun}$ and between 4 and $5 \mathrm{~m}$ on $10 \mathrm{Ju}$. Diversity values of the 1 to $5 \mathrm{~m}$ depths varied little seasonally. The depths below $5 \mathrm{~m}$ varied from 0.6 to $2.8(\bar{x}=1.6)$ and varied considerably with time. Probability of interspecific encounter (PIE) values ranged from .16 to .89 (Table 11) and, as in the preliminary study, were highly correlated with $\overline{\mathrm{d}}$ (OSL $<.001$ ). Observed trends in depth and seasonal variation were similar to those described using $\overline{\mathrm{d}}$.

The proposed models for the analysis of the variation on species composition and density with depth (models 1 and 2 ) were not satisfactory in mathematically describing the distribution of the benthic macroinvertebrates. A polynomial function of greater than third degree was always necessary to account for a significant part of the depth variation of density biomass, and number of species. Physicochemical data, expressed as linear functions (mode1 3), did not contribute significantly to an understanding of the depth distribution of the benthos. 
Table 10. Species diversity $(\bar{d}) *$ of populations of benthic macroinvertebrates by depth at Station 8 during 1975 in Ham's Lake.

\begin{tabular}{cccccc}
\hline $\begin{array}{c}\text { Depth } \\
(\mathrm{m})\end{array}$ & $\begin{array}{c}1 \\
\text { Mar }\end{array}$ & $\begin{array}{r}21 \\
\text { May }\end{array}$ & $\begin{array}{c}14 \\
\mathrm{Jun}\end{array}$ & $\begin{array}{r}10 \\
\mathrm{Ju} 1\end{array}$ & $\begin{array}{r}31 \\
\mathrm{Ju} 1\end{array}$ \\
\hline 1 & 3.3 & 3.0 & 2.9 & 3.3 & - \\
2 & 2.9 & 2.0 & 3.0 & 2.6 & 2.8 \\
3 & 2.6 & 2.6 & 2.9 & 3.1 & 2.3 \\
4 & 2.0 & 2.7 & 3.2 & 3.0 & 2.7 \\
5 & 1.9 & 2.2 & 2.2 & 2.0 & 1.4 \\
6 & 1.6 & 2.8 & 0.5 & 1.5 & 2.6 \\
7 & 1.5 & 2.4 & 0.6 & 1.5 & 1.4 \\
8 & 1.5 & 2.2 & 0.6 & 0.8 & 2.1 \\
\hline
\end{tabular}

*Values are total diversity of four pooled samples.

- = Samples not taken.

Vertical line designates beginning of pumping (i.e., 19 Jun 1975). 
Table 11. Probability of interspecific encounter (PIE)* of benthic macroinvertebrates by depth at Station 8 during 1975 in Ham's Lake.

\begin{tabular}{ccrrrr}
\hline $\begin{array}{c}\text { Depth } \\
(\mathrm{m})\end{array}$ & $\begin{array}{c}1 \\
\text { Mar }\end{array}$ & $\begin{array}{r}21 \\
\text { May }\end{array}$ & $\begin{array}{c}14 \\
\text { Jun }\end{array}$ & $\begin{array}{r}10 \\
\text { Jul }\end{array}$ & $\begin{array}{r}31 \\
\mathrm{JuI}\end{array}$ \\
\hline 1 & .84 & .80 & .78 & .85 & - \\
2 & .83 & .67 & .84 & .77 & .78 \\
3 & .79 & .79 & .84 & .82 & .62 \\
4 & .74 & .82 & .89 & .83 & .78 \\
5 & .64 & .71 & .81 & .72 & .63 \\
6 & .51 & .85 & .16 & .51 & .80 \\
7 & .52 & .76 & .17 & .51 & .49 \\
8 & .48 & .72 & .17 & .30 & .72 \\
\hline
\end{tabular}

*Values are total probability based on four pooled samples.

- = Samples not taken.

Vertical line designates beginning of pumping (i.e., 19 Jun 1975). 
CHAPTER V

DISCUSSION

Benthic Macroinvertebrate Assemblage

Sixty-seven species of benthic macroinvertebrates were collected from Ham's Lake in 1974 and 1975. This is within the range of that reported for other reservoirs in Oklahoma. Craven (1968) found 29 species, exclusive of chironomids, from Boomer Lake, a 102 ha impoundment in Stillwater, Oklahoma. More species (95 and 87, respectively) were found in Arbuckle Reservoir (Wilhm 1976) and Lake Texoma (Sublette 1957) possibly due partly to the larger size of the impoundments and drainage basins. Ransom (1969) collected only 25 species from Keystone Reservoir, a 10,000 ha impoundment of the Arkansas River, thus, the relationship of number of species and impoundment size may not hold.

Chaoborus punctipennis, Dero digitata, Procladius sp., and unidentified ceratopogonids were among the most common taxa collected in Ham's Lake. Dicrotendipes sp., Hyalella azteca, Hexagenia limbata, Stylaria lacustris and Aulodrilus pigueti were abundant at times in shallow water. The insect fauna of the various Oklahoma reservoirs was similar to that found in Ham's Lake. The more restricted oligochaetes, however, were different at each location. Craven (1968) found Branchiura sowerbyi to be the only abundant worm in Boomer Lake. 
In Keystone Reservoir, the oligochaete fauna consisted of Dero sp. and Limnodrilus hoffmeisteri (Ransom 1969). A more varied fauna was reported from Arbuckle Lake (Wilhm 1976) where 19 species of annelids, dominated by Stylaria lacustris, Dero digitata, and Aulodrilus pigueti, were found.

The density and number of species of benthic macroinvertebrates in Ham's Lake decreased during the summer. Over 4200 organisms $/ \mathrm{m}^{2}$ representing 34 taxa were taken in Mar, while the density was reduced to 787 organisms $/ \mathrm{m}^{2}$ and the number of species to 32 by $31 \mathrm{Jul}$. Similarly, Sublette (1957) noted that most macroinvertebrate populations were at peak abundance in late winter to early spring. Similar trends were reported in both Arbuckles (Wilhm 1976) and Keystone (Ransom 1969) reservoirs.

Depth Distribution of the Benthos

The shallow water sediments of Ham's Lake contained several abundant and many rare species of benthic macroinvertebrates. This generally produced high values of diversity. Several of the shallow water taxa were large, heavy-bodied taxa (e.g., astacids, odonates, sialids, and ephemerids); thus, the biomass was often high. Density and number of species steadily decreased throughout the spring and summer. Biomass and diversity values, however, showed no seasonal fluctuations.

The 4 to $5 \mathrm{~m}$ depths were the least densely populated area of the lake. Fewer species were found in these middle depths than in the shallower water causing the diversity values to be somewhat lower. Biomass was less in the middle depths as most of the larger organisms 
were rare or absent below $3 \mathrm{~m}$. As in the shallow water, there were no consistant seasonal trends in diversity or biomass, and the number of species and density decreased with time.

The benthic assemblage in the profundal zone contained one or two abundant and few rare taxa resulting in low values of species diversity. Although density often was extremely large in this zone, the dominant organism, Chaoborus, is small (Ransom 1969) and the total biomass was generally small. Between Mar and May, density and biomass of the benthos of the profundal zone decreased sharply due to an emergence of Chaoborus, while diversity and the number of species were similar. Decreased species richness during the Jun and mid-Jul samples produced low diversity values. By $31 \mathrm{Jul}$, both number of species and diversity increased to the May levels.

Variation in species diversity $(\bar{d})$ and composition of benthic macroinvertebrates with depth in the Ham's Lake is comparable to findings in other lakes. Diversity decreased with depth in Keystone Reservoir (Ransom 1969). Chironomids and oligochaetes of E1 Capitan Reservoir decreased in abundance with depth throughout the year and were more concentrated in the littoral zone during summer stratification (Inland Fisheries Branch 1970, Fast 1973). In Boomer Lake, the density distribution of macroinvertebrates was bimodal (Craven 1968). Hexagenia spp. and Tendipedidae (=Chironomidae) were concentrated in shallow water and Chaoborus mainly in the profundal zone as was found in the present study. Concentration zones for the benthos in several Michigan lakes were variable, although the profundal depths rarely supported a large density during severe stratification (Eggleton 1931). Baker (1918) found the number of species of benthic macroinvertebrates 
to increase with depth for the first 1 to $1.5 \mathrm{~m}$ then decrease in Oneida Lake. Many species were confined to narrow depth ranges, mostly in comparatively shallow water. The most pronounced decrease in species occurred from 2.5 to $5 \mathrm{~m}$. The benthic biomass of Lake Kariba was negatively correlated with depth in protected bays (McLachlan and McLachlan 1971). Most of the heavier benthic invertebrates and, thus, the concentration of biomass of Hemlock Lake, Michigan, were confined to the upper $4 \mathrm{~m}$ depths (Fast 1971).

\section{Effects of Physicochemical Conditions}

Oxygen depletion in the hypolimnion greatly affected the species richness of the benthic macroinvertebrates in the profundal zone. Oxygen concentration below $5 \mathrm{~m}$ dropped from $3.0 \mathrm{mg} / 1$ on 21 May to 0.1 $\mathrm{mg} / 1$ on 14 Jun. The number of species collected from this zone decreased during this period from 13 to five. Species diversity $(\overline{\mathrm{d}})$ showed a similar trend and decreased from 2.5 to 0.6 . The hypolimnion again contained oxygen, $2.3 \mathrm{mg} / 1$, on $10 \mathrm{Ju} 1$ and the number of species increased to 11. This increased species richness was also reflected in higher diversity values. Most of the species collected in the profundal zone in May were again found in Jul. Sialis sp., which had been previously collected only rarely below $5 \mathrm{~m}$ was abundant on $31 \mathrm{Jul}$. Oxygen concentration was not correlated with density or biomass of the profundal benthos, or with composition or distribution of the littoralsublittoral assemblage. Conductivity and $\mathrm{pH}$ of the substrate had little observable effect on the depth distribution of the benthos. $\mathrm{pH}$ was significantly (OSL < .001) negatively related to the biomass distribution in May, but at no other time. 
Except possibly in deep lakes, depth acts as a limiting factor in the distribution of benthic macroinvertebrates only in combination with other environmental factors (Cowell and Hudson 1967). During summer, thermal stratification and chemical stagnation are two of the most powerful set of factors influencing the depth distribution of the benthic fauna of several Michigan lakes (Eggleton 1931). Anoxia in the hypolimnion was given as the prime factor for the elimination of species (Cowe11 and Hudson 1967, LaRow 1970) and reduction in biomass (McLachlan and McLachlan 1971) and density (Eggleton 1931, Inland Fisheries Branch 1970) of benthic macroinvertebrates in the profundal zone. Hilsenhoff and Narf (1968) found the presence of two species of chironomids to be positively correlated to the $\mathrm{pH}$ of the substrate of various Wisconsin lakes. Topping (1971) discerned a positive correlation between the abundance of Chironomus tentans and conductivity.

\section{Effects of Artificial Destratification}

Collections of benthic macroinvertebrates in Ham's Lake of $10 \mathrm{Jul}$ were made 21 days after artificial destratification operations began. The lake was thermally destratified but the hypolimnion still contained oxygen. The composition of benthic assemblage of the profundal zone changed little from the sample of $14 \mathrm{Jun}$, although species diversity and PIE both increased, primarily because of a reduction in the abundance in the dominant species, Chaoborus. For this same reason, total density and biomass of the profundal zone was reduced. On $31 \mathrm{Jul}$, the lake was thermally and chemically destratified. Most species of benthic macroinvertebrates which had been collected in the profundal waters in the May sample, were again found in deep water, some abun- 
dant1y. This increase in species was also reflected in larger species diversity values, which are suggestive of healthier environmental conditions (Wilhm and Dorris 1968).

Eggleton (1935) suggested that the benthic assemblage undergoes four major distributional changes corresponding to the "1imnological seasons": vernal overturn, summer stagnation, autumnal overturn, and winter stagnation. Within each season, the distribution of the benthos changes only slightly. In tropical Lake Kariba, only two distinct distributional patterns, corresponding to summer stagnation and winter overturn, were found (McLachlan and McLachlan 1971). The benthic assemblage was found to change little within the period of summer stagnation. The composition and distribution of the Ham's Lake benthos probably would have remained much like it was on 14 Jun until the autumnal turnover if destratification had not been induced artificially.

Artificial destratification of eutrophic lakes has generally been beneficial (American Water Works Association 1971, Fast 1971, 1973). The abundance and depth distribution of many species of benthic macroinvertebrates increased after lake destratification (Wirth et al. 1970, Inland Fisheries Branch 1970, Fast 1973). Hypolimnion aeration (Fast 1971) of a Michigan lake enabled the zoobenthos to recolonize the profundal muds in great quantity even though the thermocline remained intact. Thus, it seems that anoxic conditions may limit profundal zone colonization by benthic macroinvertebrates. The increased heat budget of an artificially destratified reservoir (Fast 1968) has been suggested as a factor in the reduction in the standing crop of individuals and biomass of benthic species in an oligotrophic lake (Fast 1971) and 
a montane mesotrophic reservoir (Lackey 1973). In eutrophic lakes (Wirth et al. 1970, Inland Fisheries Branch 1970, Fast 1973) and a warm water mesotrophic lake (present study) the increased heat budget may not play as important role as in coldwater mesotrophic and oligotrophic lakes. However, destratification may reverse the normal aging process of a lake (Quintero and Garton 1973) and as the lake becomes more oligotrophic, thermal stress may hinder the development of the macroinvertebrate assemblage. 


\section{CHAPTER VI}

SUMMARY

1. Benthic macroinvertebrates were collected from three depths at each of three stations in Ham's Lake, Oklahoma, during summer, 1974, and eight depths at one station during spring and summer, 1975. The composition and diversity of the benthic assemblage was analyzed for variation in distribution with time and depth. The effects of artificial destratification on the benthic assemblage were also observed.

2. A total of 76 species of benthic macroinvertebrates was collected during the study. The composition and density of the benthic assemblage was similar to that of other 0klahoma reservoirs. The number of species and density of macroinvertebrates decreased from Mar to the end of Jul, 1975. Species diversity, probability of interspecific encounter, and biomass did not change significantly with time.

3. Number of species, species diversity, and probability of interspecific encounter decreased with depth on all sampling periods. The most pronounced changes occurred between 4 and $5 \mathrm{~m}$ during periods of thermal stratification and hypolimnion anoxia. Density and biomass of the assemblage decreased with depth, but the decrease could not be directly related to the physicochemical conditions of the lake. 
4. Artificial destratification removed the thermocline from Ham's Lake within 2 wk. More gradually, the deep waters were reoxygenated. Destratification did not substantially alter the depth distribution of benthic macroinvertebrates until oxygen level of the deep water was increased. Destratification and aeration enabled species of chironomids and Sialis to recolonize the profundal zone, thus increasing the number of species, density, and species diversity of the profundal benthos.

5. Increased species diversity $(\bar{d})$ has been associated with healthier environments. It was concluded that artificial destratification increased the quality of the profundal zone of Ham's Lake. 


\section{LITERATURE CITED}

Baker, F. C. 1918. The productivity of invertebrate fish food on the bottom of Oneida Lake, with special reference to mollusks. New York State Co11. Forestry, Tech. Pub. 9, 264 p.

Beck, W. M. 1968. Chironomidae. Pages V1-V22 in E. K. Parrish (ed.), Keys to water quality indicative organisms (Southeastern United States). Fed. Water Pollut. Contr. Adm.

Beck, W. M. and E. C. Beck. 1966. Chironomidae (Diptera) of Florida. 1. Pentaneurini (Tanypodinae). Bu11. Florida State Mus. 10. $305: 379$

Brinkhurst, R. 0. 1964. Studies on the North American aquatic 01igochaeta. I. Naididae and Opistocystidae. Proc. Acad. Natur. Sci. Phila. 116:195-230.

Brinkhurst, R. 0. 1965. Studies on the North American aquatic 01igochaeta. II. Tubificidae. Proc. Acad. Natur. Sci. Phila. $117: 117-172$.

Brinkhurst, R. O. and D. G. Cook. 1966. Studies on the North American aquatic 0ligochaeta. III. Lumbriculidae and additional notes and records of other families. Proc. Acad. Natur. Sci. Phila. $118: 1-33$

Brinkhurst, R. O. and B. G. Jamison. 1973. Aquatic 01igochaeta of the world. Univ. of Toronto Press, 860 p.

Cowe11, B. C. and P. L. Hudson. 1967. Some environmental factors 
influencing benthic invertebrates in two Missouri reservoirs. Reservoir Fish. Resour. Symp. 1967.

Craven, R. E. 1968. Benthic macroinvertebrates and physicochemical conditions of Boomer Lake, Payne County, Oklahoma. M.S. Thesis, Okla. State Univ,, Stillwater, $62 \mathrm{p}$.

Eggleton, F. E. 1931. A 1imnological study of the profundal bottom fauna of certain fresh-water lakes. Ecol. Monogr. 1:231-331. Eggleton, F. E. 1935. A comparative study of the benthic fauna of four northern Michigan lakes. Mich. Acad. Sci., Arts, Let. 20: $609-644$.

Fast, A. W. 1968. Artificial destratification of E1 Capitan Reservoir by aeration, part I, effects of chemical and physical parameters. Calif. Dep. Fish and Game, Fish Bu11. 141:97 p.

Fast, A. W. 1971. The effects of artificial aeration on lake ecology. Ph.D. Diss., Mich. State Univ., East Lansing, 566 p.

Fast, A. W. 1973. Effects of artificial destratification on primary production and zoobenthos of E1 Capitan Reservoir, California. Water Resour. Res. 9:607-623.

Hilsenhoff, W. L. and P. R. Narf. 1968. Ecology of Chironomidae Chaoboridae, and other benthos in 14 Wisconsin lakes. Ann. Ent. Soc. Amer. 61:1173-1181.

Hurlbert, S. H. 1971. The non-concept of species diversity: A critique and alternatives parameters. Ecology 52:577-586.

Inland Fisheries Branch. 1970. Effects of artificial destratification on distribution of bottom organisms in E1 Capitan Reservoir. Calif. Dep. Fish and Game, Fish. Bul1. 148, 30 p. Juday, C. 1922. Quantitative studies of the bottom fauna in the 
deeper waters of Lake Mendota. Wisc. Geol. Nat. Hist. Surv. Bull. $15: 461-493$.

Lackey, R. T. 1973. Bottom fauna changes during artificial reservoir destratification. Water Res. 7:1349-1356.

LaRow, E. J. 1970. The effect of oxygen tension on the vertical migration of Chaoborus 1arvae. Limnol. Oceanogr. 15:357-362.

Mason, W. T. 1973. An introduction to the identification of chironomid larvae. Anal. Qual. Contr. Lab., Nat. Environ. Res. Center, Environ. Prot. Agency, Cincinnati, Ohio, 90 p.

McLachlan, A. J. and S. M. McLachlan. 1971. Benthic fauna and sediment in the new Lake Kariba (Central Africa). Ecology 52:800-809.

Muttkowski, R. A. 1918. The fauna of Lake Mendota: A qualitative and quantitative survey with special reference to the insects. Trans. Wis. Acad. Sci., Arts. Let., 19:374-482.

Pennak, R. W. 1953. Fresh-water invertebrates of the United States. The Ronald Press Co., N. Y., 269 p.

Quintero, J. E. and J. E. Garton. 1973. A low energy lake destratifier. Trans. Amer. Soc. Agr. Engr. 16:973-976.

Ransom, J. D. 1969. Community structure of benthic macroinvertebrates and related physicochemical conditions in Keystone Reservoir, Oklahoma. Ph.D. Diss., Okla. State Univ., Stillwater, 57 p.

Saether, 0. A. 1970. A survey of the bottom fauna of the Okanagan Valley, British Columbia. Fish. Res. Board Canada, Tech. Rep. 196.

Shannon, C. D. and W. Weaver. 1963. The matematical theory of communication. Univ. Illinois Press, Urbana, $117 \mathrm{p}$.

Simpson, E. H. 1949. Measurement of diversity. Nature, London 163: 688. 
Steichen, J. M. 1974. The effect of lake destratification on water quality parameters. Ph.D. Diss., Okla. State Univ., Stillwater, $108 \mathrm{p}$.

Sublette, J. E. 1957. The ecology of the macroscopic bottom fauna in Lake Texoma (Denison Reservoir), Oklahoma and Texas. Amer. Mid. Natur. $57: 371-402$.

Toetz, D., J. Wilhm, and R. Summerfelt. 1972. Biological effects of an artificial destratification and aeration in lakes and reservoirs - analysis and bibliography. Bur. Reclamation Rep. REC-ERC72-33. U.S. Dep. Interior, Denver, Colorado, $117 \mathrm{p}$.

Topping, M. S. 1971. Ecology of larvae of Chironomus tentans in saline lakes in central British Columbia. Can. Entomol. 103:328338.

Usinger, R. L. 1971. Aquatic insects of California. Univ. Calif. Press, Berkeley, 508 p.

Weber, C. I. 1973. Macroinvertebrates in biological field and laboratory methods for measuring the quality of surface waters and effluents. Nat. Environ. Res. Center, Cincinnati.

Wilhm, J. L. 1976. Effects of artificial destratification on populations of benthic macroinvertebrates and zooplankton in Ham's Lake and Arbuckle Reservoir. Tech. Comp. Rep. Okla. Water Resour. Res. Inst., Okla. State Univ., Stillwater, 92 p.

Wilhm, J. L. and T. C. Dorris. 1968. Biological parameters for water quality criteria. BioScience 18:477-481.

Wirth, T. L., R. C. Dunst, P. D. Uttormark, and W. Hilsenhoff. 1970. Manipulation of reservoir waters for improved quality and fish population response. Res. Rep. 62, 23 pp. Wis. Dep. Natur. Resour. 
APPENDIX 
Table 12. Density (individuals $/ \mathrm{m}^{2}$ ) of benthic macroinvertebrates by station and depth in Ham's Lake on $13 \mathrm{July} 1974$.

\begin{tabular}{|c|c|c|c|c|c|c|c|c|c|c|c|c|}
\hline \multirow[b]{2}{*}{ Depth (m): } & \multicolumn{4}{|c|}{ Station 8} & \multicolumn{4}{|c|}{ Station 1} & \multicolumn{4}{|c|}{ Station 2} \\
\hline & $\overline{1}$ & 3 & 5 & $\overline{8}$ & $\overline{1}$ & 3 & 5 & $\overline{8}$ & $\overline{1}$ & 3 & 5 & $\overline{8}$ \\
\hline Dero sp. & & 14 & & & & & & & & & & 14 \\
\hline Aulodrilus pigueti & & & & & & & & & & & 100 & 29 \\
\hline Limnodrilus clap. & & 29 & & & & & 29 & & & & & 14 \\
\hline $\begin{array}{l}\text { Tubif. w/cap. ch. } \\
\text { Tubif. w/out cap. ch. } \\
\text { Hyale1la azteca }\end{array}$ & $\begin{array}{l}14 * \\
14\end{array}$ & * $29 *$ & & & $14 *$ & $14 *$ & $* \cdot 14 *$ & & $\begin{array}{l}14 * \\
43 *\end{array}$ & & & $14 *$ \\
\hline Hexagenia 1imbata & 72 & 14 & 57 & & 43 & 86 & & & 14 & 172 & 29 & \\
\hline Caenis sp. & & & & & 29 & & & & & & & \\
\hline Cloeon sp. & & & & & 14 & & & & & & & \\
\hline Sialis sp. & 72 & & & & 14 & 14 & 29 & 14 & 14 & 57 & & \\
\hline Leptoceridae & & & 14 & 14 & & & & & & & & \\
\hline Ceratopogonidae & & & & & & & & 43 & 14 & & 258 & \\
\hline Chaoborus punctipen. & & & & & & & 43 & 186 & 14 & & & 29 \\
\hline Coelotanypus sp. & & & 43 & 14 & 14 & 57 & 43 & 29 & 29 & 14 & 57 & 72 \\
\hline Procladius sp. & 258 & 416 & 86 & 29 & 560 & 602 & 158 & 158 & 229 & 100 & 43 & 86 \\
\hline Tanypus sp. & 143 & & & 14 & 100 & 29 & 129 & 416 & & 29 & 14 & 29 \\
\hline Pentaneurini & 72 & 43 & 29 & & & & 14 & & & 129 & 115 & \\
\hline Chironomus sp. & 29 & 14 & 43 & 57 & 43 & 86 & 14 & 473 & & 57 & 129 & 115 \\
\hline Cryptochironomus sp. & 14 & & & & & & & 29 & & & 14 & \\
\hline Glyptotendipes sp. & 14 & & & & & & & & & & & \\
\hline Paralauterborn. sp. & 86 & & & & & & & & 43 & & & \\
\hline Phaenopsectra sp. & & & & & 29 & & & & & & & \\
\hline Polypedilum sp. & 43 & 14 & & & 14 & 14 & 14 & & & 43 & & \\
\hline Stictochironomus sp. & 43 & & & & & & & & & & & \\
\hline Tribelos sp. & & & & & 14 & & & & & & & \\
\hline Tanytarsus sp. & 158 & 72 & 43 & & 43 & 29 & 14 & & 186 & 14 & & \\
\hline Cricotopus sp. & & & & & & & & & 14 & & & \\
\hline Chi ronomid pupae & & & & & & & & $14 *$ & & $14 \%$ & & $43 *$ \\
\hline
\end{tabular}

*These values included in density totals but not used in determining total number of species or species diversity since they are unidentifiable immature forms and probably do not represent different species。 
Table 13. Density (individuals $/ \mathrm{m}^{2}$ ) of benthic macroinvertebrates by station and depth in Ham's Lake on $30 \mathrm{July} 1974$.

\begin{tabular}{|c|c|c|c|c|c|c|c|c|c|}
\hline \multirow[b]{2}{*}{ Depth $(m):$} & \multicolumn{3}{|c|}{ Station 8} & \multicolumn{3}{|c|}{ Station 1} & \multicolumn{3}{|c|}{ Station 2} \\
\hline & 1 & 4.5 & $\overline{8}$ & $\overline{1}$ & 4.5 & $\overline{8}$ & 1 & 4.5 & $\overline{8}$ \\
\hline Aulodrilus pigueti. & & & & & & & & 14 & \\
\hline Limnodrilus udekemianus & & & & & & & 14 & & \\
\hline Tubif. w/cap. ch. & & & & & $14 *$ & & $14 *$ & & \\
\hline Hyale11a azteca & & & & & & & 14 & & \\
\hline Hexagenia 1 Imbata & 215 & & & & & & 244 & & \\
\hline Caenis sp. & 14 & & & & & & 14 & & \\
\hline Baetidae & & & & 14 & & & & & \\
\hline Epicordulia sp. & & & & 86 & & & & & \\
\hline Sialis sp. & & & & 100 & & 14 & 72 & & \\
\hline Leptoceridae & 14 & & & & & & & & \\
\hline Chaoborus punctipen. & 29 & 86 & 731 & 29 & 43 & 1406 & & & 57 \\
\hline Coelotanypus sp. & & & 14 & 14 & 14 & 14 & 43 & 100 & \\
\hline Procladius sp. & 1492 & 14 & & 316 & 301. & & 387 & 459 & \\
\hline Tanypus sp. & 230 & & 14 & 29 & 100 & & 43 & 100 & \\
\hline Pentaneurini & 43 & & & & & & 72 & 29 & \\
\hline Chironomus sp. & 158 & 14 & & 129 & 158 & 215 & & 100 & 72 \\
\hline Cryptochironomus sp. & & & & & & & 14 & & \\
\hline Dicrotendipes $s p$. & 14 & & & 29 & & & & & \\
\hline Glyptotendipes sp. & & & & & & 14 & & & \\
\hline Goeldichironomus sp. & 14 & & & & & & 29 & & \\
\hline Paralauterborn. sp. & 14 & & & & & & & & \\
\hline Phaenopsectra sp. & & & & 29 & & & 57 & & \\
\hline Polypedilum sp. & 29 & & & 43 & & & 14 & & \\
\hline Pseudochironomus sp. & 14 & & & & & & & & \\
\hline Stictochironomus sp. & & & & & & & 14 & & \\
\hline Chironomini sp. A & 14 & & & & & & & & \\
\hline Chironomini sp. B & 14 & & & & & & & & \\
\hline Chironomini sp. C & 14 & & & 14 & & & & & \\
\hline Tanytarsus sp. & 976 & & & & 14 & 14 & 473 & 14 & \\
\hline Chironomid pupae & $43 *$ & & $14 *$ & & & & $14 *$ & & \\
\hline
\end{tabular}

* See footnote on Table 12 。 
Table 14. Density (individuals $/ \mathrm{m}^{2}$ ) of benthic macroinvertebrates by station and depth in Ham's Lake on 22 August 1974.

\begin{tabular}{|c|c|c|c|c|c|c|c|c|c|}
\hline \multirow[b]{2}{*}{ Depth (m): } & \multicolumn{3}{|c|}{ Station 8} & \multicolumn{3}{|c|}{ Station 1} & \multicolumn{3}{|c|}{ Station 2} \\
\hline & 1 & 4.5 & 8 & 1 & 4.5 & 8 & 1 & 4.5 & 8 \\
\hline Nais variabilis & 57 & 57 & & & 14 & & 14 & & \\
\hline Aulodrilus pigueti & & 29 & & & & & & 72 & \\
\hline Limnodrilus cervix & & & & & 29 & 14 & & & \\
\hline Tubif. w/out cap. ch. & $43 *$ & & & & $29 *$ & $14 *$ & & & \\
\hline Astacidae & & & & & & & 14 & & \\
\hline Hyale11a azteca & & & & & & & 14 & & \\
\hline Hexagenia 1imbata & 72 & & & 29 & & & 57 & 14 & \\
\hline Caenis sp. & & & & & & & & 14 & \\
\hline Epicordulia sp. & & & & & & & 14 & & \\
\hline Macromia sp. & & & & & & & 29 & & \\
\hline Somatochora sp. & & & & 57 & & & & & \\
\hline Sialis sp. & 43 & 14 & & 14 & & & 29 & & \\
\hline Leptoceridae & 14 & & & & & & 14 & & \\
\hline Polycentropus sp. & & 14 & & & & & & & \\
\hline Ceratopogonidae & 29 & & & 86 & 43 & 29 & & 14 & \\
\hline Chaoborus punctipen. & 14 & 172 & 818 & & 43 & 4362 & 72 & 29 & 674 \\
\hline Anatopynia sp. & 14 & & & & & & & & \\
\hline Coelotanypus sp. & & 14 & & 43 & & 43 & 14 & 129 & 86 \\
\hline Pentaneura sp. & & & & 14 & & & & & \\
\hline Procladius sp. & 473 & 186 & 14 & 602 & 215 & 43 & 72 & 143 & 57 \\
\hline Tanypus sp. & 115 & & 43 & 789 & 172 & 43 & & 14 & 72 \\
\hline Pentaneurini & & & & 43 & 43 & & & & \\
\hline Chironomus sp. & 100 & 14 & 86 & 502 & 301 & 100 & & 301 & 158 \\
\hline Cryptochir abortivus & & & & 14 & & & & & \\
\hline$\underline{\text { C. }} \cdot \mathrm{sp}$. & 43 & & & 29 & & & 43 & & \\
\hline Dicrotendipes sp. & 29 & & & & & & 72 & & \\
\hline Harnischia sp. & 86 & 14 & & 316 & & & 14 & & \\
\hline Paralauterborn. sp. & & & & 29 & & & & & \\
\hline Polypedilum sp. & & & & 100 & 14 & & 29 & & \\
\hline Pseudochironomus sp. & 29 & & & & & & & & \\
\hline Tanytarsus : sp. & 502 & 29 & & 57 & & & 186 & 43 & \\
\hline Orthocladius sp. & 115 & & & & & & 29 & & \\
\hline Chironomid pupae & $14 *$ & & & $86 *$ & & & & & $14 *$ \\
\hline
\end{tabular}

*See footnote on Table 12 。 
Table 15。 Density (individuals $/ \mathrm{m}^{2}$ ) of benthic macroinvertebrates by depth in Ham's Lake on 1 March 1975.

\begin{tabular}{|c|c|c|c|c|c|c|c|c|}
\hline \multirow[b]{2}{*}{ Taxa } & \multicolumn{8}{|c|}{ Depth (m) } \\
\hline & 1 & 2 & 3 & 4 & 5 & 6 & 7 & 8 \\
\hline Hydra sp. & & 22 & & & & & & \\
\hline Dero digitata & 4575 & 506 & 172 & & 11 & 108 & 64 & 215 \\
\hline Nais sp. & 32 & & & & & & & \\
\hline Stylaria lacustris & 247 & 22 & & & & & & \\
\hline Aulodrilus pigueti & 3337 & & & & 86 & 161 & 11 & 11 \\
\hline Ilyodrilus sp. & 1388 & 11 & 22 & & & & & \\
\hline Limnodrilus cervix. & & & 11 & & & & & \\
\hline L. claparedianus & 97 & & & & & & & \\
\hline Tubif. w/cap. ch. & $118 *$ & & & & & & & \\
\hline Tubif. w/out cap. ch. & $43 *$ & $97 *$ & $54 *$ & $11 *$ & & & & $22 *$ \\
\hline Hydracarina & 32 & 11 & & 11 & & & & \\
\hline Hyale11a azteca & 527 & 11 & & & & & & \\
\hline Hexagenia 1imbata & 22 & 484 & 64 & 64 & & 11 & & 11 \\
\hline Caenis sp. & 151 & 11 & & & & & & \\
\hline Gomphus sp. & & 11 & & & & & & \\
\hline P1athemis sp. & 32 & & & & & & & \\
\hline Ischnura sp. & 43 & 43 & & & & & & \\
\hline Sialis sp. & 54 & 11 & & & 11 & 22 & & \\
\hline Oecetis $\mathrm{sp}$. & 140 & 11 & & & & 11 & & \\
\hline Berosus sp. & 32 & & & & & & & \\
\hline Ceratopogonidae & 2400 & 355 & 161 & & & & & \\
\hline Chaoborus punctipen. & 118 & 258 & 355 & 22 & 560 & 1991 & 2120 & 4101 \\
\hline Coelotanypus sp. & 118 & 118 & 11 & & 108 & 377 & 549 & 646 \\
\hline Procladius sp. & 312 & 947 & 420 & 22 & 204 & 183 & 334 & 721 \\
\hline Chironomus sp. & 22 & 22 & & & 11 & 11 & 22 & 97 \\
\hline Cryptochironomus sp. & & 32 & 22 & & 11 & 11 & 97 & 32 \\
\hline Dicrotendipes $s p$. & 1108 & & & & & & & \\
\hline Paralauterborn. sp. & 312 & & & & & & & \\
\hline Polypedilum sp. & 97 & & & & & & & \\
\hline Tribelos sp. & 54 & & & & & 11 & & \\
\hline Micropsectra sp. & 108 & & 11 & & & 11 & & \\
\hline Tanytarsus sp. & 883 & 64 & 54 & 14 & & & & \\
\hline Psectrocladius sp. & 11 & & & & 11 & & & 22 \\
\hline Pisidium sp. & & 11 & & & & & & \\
\hline Gyralus sp. & 204 & & & & & & & \\
\hline Physa sp. & 22 & & & & & & & \\
\hline
\end{tabular}

*See footnote on Table 12 . 
Table 16. Density (individuals $/ \mathrm{m}^{2}$ ) of benthic macroinvertebrates by depth in Ham's Lake on 21 May 1975.

\begin{tabular}{|c|c|c|c|c|c|c|c|c|}
\hline \multirow[b]{2}{*}{ Taxa } & \multicolumn{8}{|c|}{ Depth (m) } \\
\hline & 1 & 2 & 3 & 4 & 5 & 6 & 7 & $\overline{8}$ \\
\hline Dugesia sp. & 118 & & & & : & & & \\
\hline Chaetogaster sp. & 125 & & & & & & & \\
\hline Dero digitata & 3530 & 646 & 700 & 108 & 301 & 108 & 54 & 237 \\
\hline Stylaria 1acustris & 1259 & & & & & 32 & & \\
\hline Aulodrilus pigueti & 86 & & & & & & & \\
\hline Ilyodrilus sp. & 624 & & & . & & & & \\
\hline Limnodrilus cervix & 43 & & 108 & 151 & & & & \\
\hline$\underline{\text { L. claparedianus }}$ & & & & 11 & & & & \\
\hline Tubif. w/out cap. ch. & $32 *$ & & $172 *$ & & $11 *$ & & $11 *$ & \\
\hline Astacidae & 11 & & & & & & & \\
\hline Hyale11a azteca & 125 & & & & & & & \\
\hline Hexagenia limbata & 237 & 172 & 441 & 231 & 161 & 86 & & \\
\hline Caenis sp. & 97 & & & & & & & \\
\hline Centroptilum sp. & 11 & & & & & & & \\
\hline Gomphus sp. & 11 & & & & & & & \\
\hline Sympetrum sp. & 11 & & & & & & & \\
\hline Ischnura sp. & 11 & & & & & & & \\
\hline Sialis sp. & 22 & 43 & 172 & & 11 & & & \\
\hline Decetis sp. & 11 & & & & & & & \\
\hline Ceratopogonidae & 1216 & 64 & 377 & 151 & 54 & 75 & 54 & 108 \\
\hline Chaoborus punctipen. & 11 & & & 11 & & & 65 & 86 \\
\hline Ablabesmia sp. & 11 & & & & & & & \\
\hline Coe1otanypus sp. & 32 & & 43 & 32 & 11 & 54 & 194 & 43 \\
\hline Procladius sp. & 850 & 258 & 172 & 97 & 65 & 75 & 11 & 22 \\
\hline Chironomus sp. & & & & & & & & 11 \\
\hline Dicrotendipes sp. & 22 & & & & & & 11 & 22 \\
\hline Endochironomus sp. & 11 & & & & & & & \\
\hline Harnischia sp. & & & 11 & 11 & & 22 & 11 & \\
\hline Lauterbornie11a sp. & & & & & 11 & & & \\
\hline Paralauterborn. sp. & 140 & & & & 11 & & & \\
\hline Polypedilum sp. & 22 & & & & & & & \\
\hline Pseudochironomus sp. & & & & & & & 11 & \\
\hline Micropsectra sp. & 54 & & 11 & & & & & \\
\hline Tanytarsus sp. & 474 & 54 & 11 & & & 22 & 22 & \\
\hline Chironomid pupae & $11 *$ & $11 *$ & & & & $22 *$ & & \\
\hline Pisidium sp. & & 11 & 11 & 11 & 11 & & & \\
\hline Gyralus sp. & 11 & & & & & & & \\
\hline Physa sp. & 11 & & & & & - & & \\
\hline
\end{tabular}

*See footnote on Table 12 . 
Table 17. Density (individuals $/ \mathrm{m}^{2}$ ) of benthic macroinvertebrates by depth in Ham's Lake on 14 June 1975.

\begin{tabular}{|c|c|c|c|c|c|c|c|c|c|}
\hline \multirow[b]{2}{*}{ Taxa } & \multicolumn{9}{|c|}{ Depth (m) } \\
\hline & 1 & 2 & 3 & & 4 & 5 & 6 & 7 & 8 \\
\hline Dugesia sp. & 366 & & & & & & & & \\
\hline Nematoda & 11 & 11 & 11 & & & & & & \\
\hline Chaetogaster sp. & 11 & & & & & & & & \\
\hline Dero digitata & 2400 & 183 & 226 & & 54 & 11 & 11 & 22 & 11 \\
\hline Stylaria 1acustris & 1141 & & & & & & & & \\
\hline Aulodrilus pigueti & 75 & & 11 & & & & & & \\
\hline Limnodrilus hoffmeist. & 86 & & 108 & & & & & & \\
\hline Tubifex tubifex & 334 & & & & 75 & & & & \\
\hline Tubif. w/out cap. ch. & $75 *$ & & $75 *$ & & $75 *$ & $32 *$ & & & \\
\hline Hydracarina & 11 & & & & & 11 & & & \\
\hline Astacidae & 32 & & & & & & & & \\
\hline Hya1e11a azteca & 635 & & & & & & & & \\
\hline Hexagenia 1imbata & 86 & 86 & 204 & & 43 & & & & \\
\hline Gomphus sp. & 11 & & & & & & & & \\
\hline Coenagrionidae & 11 & & & & & & & & \\
\hline Sia1is $s p$. & 75 & 108 & 237 & i & 32 & & & & \\
\hline Molanna sp. & 11 & & & & & & & & \\
\hline Ceratopogonidae & 312 & 43 & 129 & & 32 & 11 & & & 11 \\
\hline Chaoborus punctipen. & & 43 & & & 22 & 22 & 581 & 775 & 646 \\
\hline Ablabesmia sp. & 32 & 11 & 11 & & 11 & & & & \\
\hline Coelotanypus sp. & & & 43 & & 22 & & 32 & 22 & 32 \\
\hline Procladius sp. & 64 & 54 & 64 & & 22 & & & & \\
\hline Tanypus sp. & & & 22 & & & & 11 & 32 & 11 \\
\hline Dicrotendipes sp. & 22 & & & & & & & & \\
\hline Harnischia sp. & & 11 & & & & & & & \\
\hline Parachironomus sp. & 32 & & & & & & & & \\
\hline Paralauterborn. sp. & & 11 & & & & & & & \\
\hline Polypedilum sp. & 64 & 11 & & & & & & & \\
\hline Stenochironomus sp. & 11 & & & & & & & & \\
\hline Tribelos sp. & 22 & & & & & & & & \\
\hline Rheotanytarsus sp. & 108 & 11 & & & 11 & & & & \\
\hline Tanytarsus sp. & & 22 & & & & & & & \\
\hline Pisidium sp. & & & & & 54 & 32 & & & \\
\hline
\end{tabular}

*See footnote on Table 12 。 
Table 18. Density (individuals $/ \mathrm{m}^{2}$ ) of benthic macroinvertebrates by depth in Ham's Lake on $10 \mathrm{July} 1975$.

\begin{tabular}{|c|c|c|c|c|c|c|c|c|}
\hline & & & & De & (m) & & & \\
\hline Taxa & 1 & 2 & 3 & 4 & 5 & 6 & 7 & 8 \\
\hline Nematoda & & 11 & & & & & & \\
\hline Dero digitata & 344 & 904 & 527 & 97 & 43 & 32 & 11 & \\
\hline Limnodrilus cervix & & & 32 & & & & & \\
\hline$\underline{L}$. hoffmeisteri & 11 & & 11 & & & & & \\
\hline Tubifex tubifex & 97 & & & : & & & & \\
\hline Tubif. w/out cap. ch. & & & $215 *$ & $43 *$ & $11 *$ & & & $11 *$ \\
\hline Hydracarina & 22 & 11 & & & & & & \\
\hline Hyale11a azteca & 11 & & & & & & & \\
\hline Hexagenia 1imbata & & 161 & 140 & 32 & & 11 & & \\
\hline Caenis sp. & 11 & & & & & & & \\
\hline Epicordulia sp. & 32 & & & & & & & \\
\hline Coenagrionidae & 32 & & & & & & & \\
\hline Sialis sp. & 129 & 183 & 215 & 32 & & & & \\
\hline Oecetis sp. & 11 & & & & & & 11 & \\
\hline Halipus sp. & 22 & & & & & & & \\
\hline Ceratopogonidae & 108 & 86 & 32 & 43 & & 11 & & 32 \\
\hline Chaoborus punctipen. & & 11 & 43 & 43 & 75 & 140 & 226 & 420 \\
\hline Ablabesmia sp. & 22 & 118 & 86 & 11 & & 11 & & \\
\hline Coelotanypus sp. & 11 . & 11 & 32 & 11 & 54 & & 54 & 32 \\
\hline Procladius sp. & 54 & 710 & 388 & 161 & 11 & & & \\
\hline Tanypus sp. & & & 11 & & & & 22 & \\
\hline Chironomus sp. & & & & & & & & 11 \\
\hline Dicrotendipes sp. & 11 & & & & & & & \\
\hline Harnischia sp. & & 97 & & & & & & \\
\hline Parachironomus sp. & 11 & & 11 & & & & & \\
\hline Paralauterborn. sp. & & 22 & & & & & & \\
\hline Phaenopsectra sp. & 118 & & & & & & & \\
\hline Polypedilum sp. & 11 & & 11 & 11 & & & & \\
\hline Tribelos sp. & 11 & & & & & & & \\
\hline Tanytarsus sp. & & 140 & 97 & 11 & & & & \\
\hline Chironomini sp. F & & & & & & & 11 & \\
\hline Chironomid pupae & & $11 *$ & $11 *$ & & & & & \\
\hline Pisidium sp. & & & 43 & 11 & & & & \\
\hline
\end{tabular}

* See footnote on Table 12 。 
Table 19。 Density (individual $/ \mathrm{m}^{2}$ ) of benthic macroinvertebrates by depth in Ham's Lake on 31 July 1975 .

\begin{tabular}{|c|c|c|c|c|c|c|c|c|}
\hline \multirow[b]{2}{*}{ Taxa } & \multicolumn{8}{|c|}{ Depth (m) } \\
\hline & 1 & 2 & 3 & 4 & 5 & 6 & 7 & 8 \\
\hline Dero digitata & NS & 398 & 1270 & 151 & 32 & 22 & & 11 \\
\hline Aulodrilus pigueti & & 11 & 151 & 11 & & 11 & & \\
\hline Limnodrilus cervix & & & 54 & 11 & & & & 11 \\
\hline Tubif. w/cap. ch. & & & $11 *$ & $43 \%$ & & & & \\
\hline Tubif. w/out cap. ch. & & & $237 *$ & & & & & \\
\hline Hydracarina & & & 11 & & & 11 & & \\
\hline Hexagenia limbata & & 22 & 32 & & & & & \\
\hline Caenis sp. & & & 11 & & & & & \\
\hline Sialis sp. & & 64 & 118 & 11 & & 118 & 22 & 11 \\
\hline Ceratopogonidae & & & 22 & 43 & 32 & 43 & 54 & 204 \\
\hline Chaoborus punctipen. & & 11 & 22 & 22 & 11 & 140 & 344 & 215 \\
\hline Ablabesmia sp. & & 11 & 22 & 11 & & & & \\
\hline Coelotanypus sp. & & 54 & 11 & 32 & & 183 & 64 & 118 \\
\hline Procladius sp. & & 172 & 248 & 43 & & 32 & 11 & 22 \\
\hline Tanypus sp. & & 43 & 11 & & & & & 11 \\
\hline Pentaneurini & & 11 & & & & & & \\
\hline Chironomus sp. & & & & & & 22 & & \\
\hline Dicrotendipes sp. & & 11 & & & & & & \\
\hline Harnischia sp. & & 86 & & & & & & \\
\hline Parachironomus sp. & & & & & & & & \\
\hline Paralauterborn. sp. & & 11 & & & & & & \\
\hline Polypedilum sp. & & & 32 & & & & & \\
\hline Rheotanytarsus & & & 11 & & & & & \\
\hline Tanytarsus sp. & & 54 & 97 & 22 & & & & \\
\hline Pisidium sp. & & & 11 & & & 11 & & \\
\hline
\end{tabular}

NS - Not sampled due to dense growth of aquatic macrophytes.

*See footnote on Table 12 。 


\author{
$d$ \\ VITA \\ Car1 James Ferraris, Jr. \\ Candidate for the Degree of \\ Master of Science
}

Thesis: DISTRIBUTION OF BENTHIC MACROINVERTEBRATES IN AN ARTIFICIALLY DESTRATIFIED RESERVOIR

Major Field: Zoology

Biographical:

Personal Data: Born in Rochester, New York, October 28, 1950, the son of Carl J. and Lucy D. Ferraris.

Education: Graduated from John Marshall High School, Rochester, New York on June, 1968; received a Bachelor of Science degree in biological sciences from Cornell University, Ithaca, New York, in May, 1972; completed requirements for a Master of Science at Oklahoma State University in May, 1976.

Professional Experience: Science aid, U.S. Environmental Protection Agency July, 1970 to August, 1971; Junior Research Biologist, Ichthyological Associates, Inc., Berwick, Pennsylvania, June, 1972 to August, 1973; Graduate Teaching Assistant, Oklahoma State University, Stillwater, Oklahoma January, 1974 to May, 1975, and February to May, 1976; Graduate Research Assistant, Oklahoma State University, Stillwater, Oklahoma, September to December, 1973, July, 1974 to January, 1975, and June to December, 1975; Aquatic Ecologist, Aquatic Life Consultants, Inc., Stillwater, Oklahoma, February, 1974 to January, 1975; Aquatic Ecologist, Techrad, Inc., Oklahoma City, Oklahoma, July, 1975 to February, 1976.

Professional Affiliations: American Society of Ichthyologists and Herpatologists; American Fisheries Society; Society of American Zoologists; North American Benthological Society. 